\title{
Sedimentary record of plutonium in the North Yellow Sea and the response to catchment environmental changes of inflow rivers
}

Xu, Yihong; Pan, Shaoming; Gao, Jianhua; Hou, Xiaolin; Ma, Yongfu; Hao, Yongpei

Published in:

Chemosphere

Link to article, DOI:

10.1016/j.chemosphere.2018.05.082

Publication date:

2018

Document Version

Peer reviewed version

Link back to DTU Orbit

Citation (APA):

Xu, Y., Pan, S., Gao, J., Hou, X., Ma, Y., \& Hao, Y. (2018). Sedimentary record of plutonium in the North Yellow Sea and the response to catchment environmental changes of inflow rivers. Chemosphere, 207, 130-138. https://doi.org/10.1016/j.chemosphere.2018.05.082

\section{General rights}

Copyright and moral rights for the publications made accessible in the public portal are retained by the authors and/or other copyright owners and it is a condition of accessing publications that users recognise and abide by the legal requirements associated with these rights.

- Users may download and print one copy of any publication from the public portal for the purpose of private study or research.

- You may not further distribute the material or use it for any profit-making activity or commercial gain

- You may freely distribute the URL identifying the publication in the public portal 


\section{Sedimentory records of plutonium Plutonium-in}

2 sediments of the North Yellow Sea and its-response

3 to catchment environment of inflow rivers

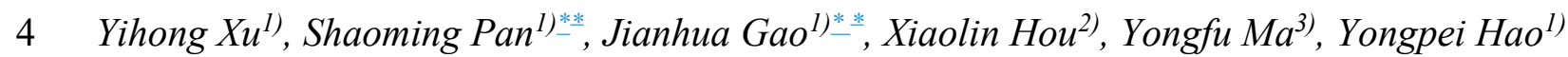

5 1) The Key Laboratory of Coastal and Island Development of Ministry of Education, School of

6 Geographic and Oceanographic Sciences, Nanjing University, Nanjing 210023, China

$7{ }^{2)} \mathrm{Xi}$ 'an AMS Center, SKLLQG, Institute of Earth Environment, CAS, Xi'an 710061, China

8 3) The Key Laboratory of Environmental Radiation Monitoring of Ministry of Environmental

9 Protection; Radiation Monitoring Department, Environmental Radiation Monitoring Technical

10 Center of Ministry of Environmental Protection, Hangzhou 310012, China

11 ABSTRACT: Plutonium isotopes were first determined in surface and core sediment samples

12 collected from the northern North Yellow Sea to elucidate their source terms and deposition

13 process as well as response to the environment. ${ }^{240} \mathrm{Pu} /{ }^{239} \mathrm{Pu}$ atomic ratios in all sediments showed

14 the typical global fallout value of $\sim 0.18$ without any influences from the nuclear weapons tests

Corresponding authors

E-mail: span@nju.edu.cn (S. M. Pan)

jhgao@nju.edu.cn (J.H. Gao) 
15 conducted recently in the North Korea or early in the Pacific Proving Ground. The large

16 variation of ${ }^{239+240} \mathrm{Pu}$ activities $(0.022-0.515 \mathrm{mBq} / \mathrm{g})$ in surface sediments was mainly attributed

17 to the re-suspension and transportation of fine sediments influenced by the Liaonan Costal

18 Current. Based on the two Pu depth profiles with easily observed onset (1952) and global fallout

19 peaks (1963), ${ }^{239+240} \mathrm{Pu}$ served as a valid time mark in the coastal sedimentary system. Riverine

20 input plutonium contributes only $15-27 \%$ to the total global fallout inventory $\left(92.5-108.8 \mathrm{~Bq} / \mathrm{m}^{2}\right)$

21 in the study area, much lower than that in the Yangtze River estuary (77-80\%), indicating a

22 better soil conservation in the northeast China compared to the Yangtze River's drainage basin.

23 Riverine input $\mathrm{Pu}$ increased after 1980s reflected the increased soil erosion degree caused by the

24 land use and cover change due to the increased human activities in the northeast China. These

25 results demonstrated that plutonium is a good indicator for studying sedimentary process and its

26 response to the environment in the coastal area.

27 Key words: Plutonium, North Yellow Sea, sediment, isotopic ratio, chronological marker,

28 riverine input

29

$30 \quad$ Highlights

31 1. The atmospheric fallout is the dominant source of Pu in the North Yellow Sea.

32 2. PPG input Pu has no influence on the North Yellow Sea.

33 3. Riverine input Pu contributed about $15-27 \%$ to the northern North Yellow Sea

34 4.Riverine input Pu contributed much less in the NYS than in the Yangtze River estuary.

35 5. Pu is a good indicator to study the sediment process in coast sea. 


\section{INTRODUCTIONIntrduction}

37 Plutonium isotopes $\left({ }^{239} \mathrm{Pu}\right.$ and $\left.{ }^{240} \mathrm{Pu}\right)$ have been substantially introduced to the marine 38 environment mainly from the global fallout of extensive atmospheric nuclear weapons tests

39 (NWT) since 1945. The global fallout has not equally dispersed on the ocean surface, but had a 40 maximum deposition over the mid-latitude in the western North Pacific Ocean due to the 41 geographic and climatological conditions_(Gatsaud et al., 2011; Hirose et al., 2001). ${ }^{1-2}$ In 42 addition to the global fallout, close-in fallout from the Pacific Proving Ground (PPG), where a 43 series of U.S. nuclear tests were conducted in the 1940s-1950s, was a second significant source 44 of $\mathrm{Pu}$ in the North Pacific Ocean. ${ }^{239} \mathrm{Pu}\left(\mathrm{T}_{1 / 2}=24110 \mathrm{yr}\right)$ and ${ }^{240} \mathrm{Pu}\left(\mathrm{T}_{1 / 2}=6563 \mathrm{yr}\right)$ in the marine 45 environment are of great environmental concern due to their high chemical toxicity and long 46 half-lives. Besides to be good indicators for radioactive pollution, $\mathrm{Pu}$ isotopes can also serve as 47 useful geochemical tracers for better understanding a variety of marine processes (Lindahl et al., $48 \quad 2010)^{3}$

49 With the high particle affinity, $\mathrm{Pu}$ isotopes entered into the oceans can be effectively 50 scavenged by settling particulate matter from the water column to the seafloor sediments. This 51 process is well known as "boundary scavenging" and generally enhanced in ocean 52 boundaries/margins, where are usually areas with high biological productivity, high particle flux 53 and sediment accumulation_(Hong et al., 2011). ${ }^{4}$ Seafloor sediments are therefore the ultimate

54 sink of $\mathrm{Pu}$ entering the marine environment, and preserve $\mathrm{Pu}$ deposition history, from which

55 valuable information of impact of human activities on the marine environment and its changes 56 over time can be deduced. With the well constrained release history of the global fallout $\mathrm{Pu}$ from 57 the NWTs, which began in the late 1940s and had a distinct deposition maximum in 1963 58 (UNSCEAR, 2000), ${ }^{5}$ undisturbed sediment recording these two events can be identified and thus 
59 used for dating purpose (Corcho-Alvarado et al., 2014). ${ }^{6}$ With the recent rapid development in

60 analytical procedures and mass spectrometric measurements (Qiao et al., 2009), ${ }^{7-8}{ }^{239+240} \mathrm{Pu}$ has

61 been suggested as a chronostratigraphic marker for modern sediments dating in both freshwater 62 bodies (e.g. lakes and river estuaries) (Ketterer et al., 2004; Wu et al., 2010; Zheng et al., 2008) ${ }^{9-}$

$63{ }^{12}$-and coastal areas (Corcho-Alvarado et al., 2014; Hancock et al., 2011), ${ }^{6,13}$ and shown some

64 advantages to the conventional ${ }^{137} \mathrm{Cs}$ method, such as more precise determination especially in 65 marine sediments(Hancock et al., 2011) ${ }^{13}$ and additional chronometers associated with changes 66 in ${ }^{240} \mathrm{Pu} /{ }^{239} \mathrm{Pu}$ atomic ratios for Pu fallout during the 1950s and $1960 \mathrm{~s}$ (Koide et al., 1985) ${ }^{14}$ as 67 well as fallout from the 1986 Chernobyl accident in some European areas (Ketterer et al., 2004). 689

69 In the past decades, numerous studies have been carried out to investigate source terms, 70 transport, and scavenging and deposition processes of $\mathrm{Pu}$ isotopes in China marginal seas _Hong 71 et al., 2006; Huh \& Su, 1999; Lee et al., 2003; Liu et al., 2011; Nagaya \& Nakamura, 1992; Pan 72 et al., 2011; Su \& Huh, 2002; Wang et al., 2005; Wang et al., 2017; Wu et al., 2014; Zheng \& 73 Yamada, 2006). $\cdot{ }^{15-27}$ However, most of these studies concentrated in the East China Sea ESC and 74 the Yangtze River Estuary. Regarding Pu isotopes in the Yellow Sea (YS)-sediments, only 75 several data points have been reported in the Souththern Yellow Sea (SYC) and Jiangsu tidal 76 flats (Hong et al., 2006; Liu et al., 2013; Nagaya \& Nakamura, 1992). ${ }^{15,21,25}$ No Pu data in the

77 North Yellow Sea (NYS) sediments is available. The YS-Yellow Sea located between mainland

78 China and the Korean Peninsula is a semi-closed shallow marginal sea. It is normally divided

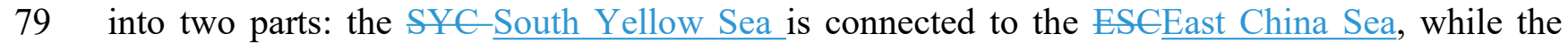
80 NYS, considered in the present study, is adjacent to the Bohai Bay and surrounded by the 81 Liaodong Peninsula, Shandong Peninsula and Korean Peninsula. The coastal areas of the NYS 
82 are densely populated areas, where are very close to North Korea. Nuclear activities including

83 NWTs in North Korea have caused a great concern on the radiation exposure to the public in the

84 past years. The Hongyanhe nuclear power plant (NPP) with 4 units located in Dalian $\left(39.792^{\circ} \mathrm{N}\right.$,

$\left.85121.475^{\circ} \mathrm{E}\right)$ on the Liaodong Peninsula has already being in operation from $20^{\text {th }}$ September 2016.

86 In addition, there are plans to build 4 more NPPs in China's three northeast provinces. Potential

87 releases of radioactive materials including $\mathrm{Pu}$ from the $\mathrm{NPP}_{s}$ to the surrounding environment and

88 the consequences are also a major concern of the local inhabitants and the authorities.

89 In the north coast of the NYS, major rivers flowing into the sea include Yalu River, Dayang

90 River and Biliu River. These rivers play important roles in the transportation of terrigenous

91 sediments to the northern NYS. The fluvial sediment discharges providing significant source of

92 sediments in the coastal sea (Liu et al., 2013), are related to the soil erosion degree in river basins

93 and can vary in response to climate changes and human activities in the catchment, which can be

94 well reflected in the coastal sedimentary system. Thus investigation of the sediment deposition

95 process in the coastal sea and its dynamics is of great significance for evaluating water and soil

96 loss in river basins and comprehensive understanding the land-ocean interaction within the

97 coastal areas.

In this work, surface sediments and sediment cores were collected in the northern NYS

99 (Figure 1) and analyzed for ${ }^{239} \mathrm{Pu}$ and ${ }^{240} \mathrm{Pu}$, aiming (1) to investigate the source term, distribution

100 and deposition process of $\mathrm{Pu}$ in the study area; (2) to identify the contributions of direct

101 deposition and riverine input by the deposition history of $\mathrm{Pu}$, as well as to evaluate the water loss

102 and soil erosion in the coastal major watersheds and its response to elimate change and-human

103 activities; (3) to provide baseline data of $\mathrm{Pu}$ for environmental risk assessment in relation to the

104 nuclear activities in North Korea and the Hongyanhe NPP. 
106 2. MATERIALS AND METHODS $\underline{\underline{a} \text { aterials and methods }}$

$107 \quad 2.1$ Study Area

108 The study area was located along the southeastern coast of the Liaodong Peninsula, in the

109 northern NYS (Figure 1). Many islands are scattered along the coast (e.g. Shicheng Island,

110 Changshan Island, etc.), resulting in the complex subwater topography in the study area (Chen et

111 al., 2013). ${ }^{28}$ There are a number of rivers flowing into the NYS, among which the Yalu River is

112 the largest one with the sediment discharge of $113 \times 10^{4}$ tons/a (State Oceanic Administration,

113 1998). ${ }^{29}$ Besides, the Dayang River and Biliu River with the sediment discharges of $69.3 \times 10^{4}$

114 tons/a and $53.3 \times 10^{4}$ tons/a also contribute significant amounts of sediments to the study area

115 (Bao \& Du, 1999). ${ }^{30}$ The water circulation in the study area is dominated by the Liaonan Coastal

116 Current (LCC), which is formed by the Yalu River Diluted Water Mass and flows constantly

117 along the southeast coast of the Liaodong Peninsula to the Bohai Strait. It has been reported that

118 the Yalu River derived sediments were re-suspended and then transported by the LCC

119 southwestward for a long distance and re-deposited along the southeast coast of Liaodong

120 Peninsula_(Chen et al., 2013). ${ }^{28}$ In addition to the LCC, the strong Yellow Sea Warm Current

121 (YSWC) in winter, the Yellow Sea Coastal Current (YSCC) and the West Korean Coastal

122 Current (WKCC) might also affect the material transport in the study area.

123 2.2 Sample collection and pretreatment

124 Sampling was conducted onboard in July 2016 and March 2017, respectively. Eight surface

125 sediments (0-2 cm depth) and two sediment cores (NYSC-01 with water depth of $10 \mathrm{~m}$ and

126 NYSC-02 with water depth of $20 \mathrm{~m}$ ) were collected using the grab buckets and a gravity

127 sampler, respectively. The sediment cores were sliced in $2 \mathrm{~cm}$ intervals and weighed 
128 immediately, $2 \mathrm{~g}$ of sediment was taken from each surface and interval sediment sample for the

129 analysis of the grain size composition by the Malvern Mastersize 2000 laser granulometer

130 (measuring range $0.02-2000 \mu \mathrm{m}$, with a duplicate measurement error of $<3 \%$ ). The remained

131 sediment samples were freeze-dried and reweighed to determine mass depths in the laboratory.

132 Dried samples were then ground to fine powder for $\mathrm{Pu}$ isotopes analysis.

$133 \quad 2.3$ Determination of $\mathrm{Pu}$ isotopes

134 The method for $\mathrm{Pu}$ isotopes analysis is similar as described in our previous publications $\underline{\mathrm{Xu}}$ et

135 al., 2014. ${ }^{31-34}$ Briefly, approximately $5 \mathrm{~g}$ of dried sediments for each sample were weighed to a

136 beaker and ashed at $550{ }^{\circ} \mathrm{C}$ overnight to decompose the organic matter as well as to obtain

137 organic matter (OM)-content by calculating the mass loss in this process. After being spiked with 138 a known amount of ${ }^{242} \mathrm{Pu}(\mathrm{ca} .1 \mathrm{mBq})$ as a chemical yield monitor (the ${ }^{242} \mathrm{Pu}$ added to the ashed

139 aliquot does not cover the losses during the mineralization, but they should be negligible), the

140 samples were leached using aqua regia for $2 \mathrm{~h}$ at $200{ }^{\circ} \mathrm{C}, \mathrm{Pu}$ in the leachate was co-precipitated

141 with iron hydroxides to remove the major matrix components. After centrifuge, the precipitate

142 was dissolved with concentrated $\mathrm{HCl}$. Then $\mathrm{Pu}$ in the solution was reduced to $\mathrm{Pu}(\mathrm{III})$ by adding

143 about $300 \mathrm{mg}$ of $\mathrm{K}_{2} \mathrm{~S}_{2} \mathrm{O}_{5}$ and then oxidized to $\mathrm{Pu}(\mathrm{IV})$ with conc. $\mathrm{HNO}_{3}$. A $15 \mathrm{~mL}$ AG1-×4 anion-

144 exchange column and a $2 \mathrm{~mL}$ TEVA column were successively used for separation and

145 purification of $\mathrm{Pu}$ isotopes. The final sample solution prepared in $3 \mathrm{~mL}$ of $0.5 \mathrm{~mol} \mathrm{~L}-1 \mathrm{HNO}_{3}$ was

146 analyzed for $\mathrm{Pu}$ isotopes $\left({ }^{239} \mathrm{Pu},{ }^{240} \mathrm{Pu},{ }^{242} \mathrm{Pu}\right)$ using a section field ICP-MS (SF-ICP-MS)

147 (Element 2, Thermo Scientific, Bremen, Germany). An APEX-Q high efficiency sample

148 introduction system (Elemental Scientific Inc., Omaha, NE, USA) combined with a membrane

149 desolvation unit (ACM) and a conical concentric nebulizer was used to introduce sample

150 solution to the ICP-MS. All the measurements were made in the self-aspiration mode with an 
151 uptake rate of $\sim 0.2 \mathrm{~mL} \mathrm{~min}^{-1}$ to reduce the risk of contamination from the long peristaltic pump 152 tubing. $0.1 \mathrm{ng} \mathrm{mL}^{-1} \mathrm{U}$ standard solution was used for tuning SF-ICP-MS before the samples 153 were measured each time. The ${ }^{242} \mathrm{Pu}$ standard solution in the same media as the samples and 154 procedure blanks were measured with the samples. The concentrations of ${ }^{239} \mathrm{Pu}$ and ${ }^{240} \mathrm{Pu}$ in the 155 sample were calculated by the measured signal intensities of ${ }^{239} \mathrm{Pu},{ }^{240} \mathrm{Pu}$ and ${ }^{242} \mathrm{Pu}$ and the 156 amount of ${ }^{242} \mathrm{Pu}$ added to the sample before chemical separation. ${ }^{242} \mathrm{Pu}$ was used in this 157 procedure as both dilution isotope and chemical yield monitor.

\section{3. Results and discussions ESULTS AND-BISCUSSION}

159 3.1 Source terms of Pu isotopes in the northern NYS

160 Since the isotopic composition of $\mathrm{Pu}$ is related to its production and release, the atomic ratio 161 of ${ }^{240} \mathrm{Pu} /{ }^{239} \mathrm{Pu}$ in environmental samples could be used to identify the source term of plutonium 162 contamination. It has been well proved that the global fallout has an average ${ }^{240} \mathrm{Pu} /{ }^{239} \mathrm{Pu}$ ratio of

1630.18 (Kelley et al., 1999; Warneke et al., 2002). ${ }^{35-37}{ }^{240} \mathrm{Pu} /{ }^{239} \mathrm{Pu}$ atomic ratios for weapons-grade

164 Pu were reported to be very low $(0.01-\leq 0.07)$ (Lee \& Clark, 2005), ${ }^{38-39}$ while much higher values 165 were reported in materials of nuclear power reactors (0.2-0.8, depending on the reactor type and 166 fuel burn-up)_(Muramatsu et al., 2000; Warneke et al., 2002). ${ }^{37,40}$ It has also been found that 167 different test series have different atomic ratio. For example, the ${ }^{240} \mathrm{Pu} /{ }^{239} \mathrm{Pu}$ atomic ratios in the 168 close-in fallout at the Nevada test site are generally very low with an average of 0.035 (Buesseler, 169 \& Sholkovitz, 1987), ${ }^{41}$ while close-in fallout in the PPG of the Marshall Islands in the 1950s is 170 characterized by higher ratios of 0.30-0.36 (Buesseler, 1997; Koide et al., 1985; Muramatsu et al.,

$1712001) \cdot{ }^{14,42-43}$ Such characteristic of PPG-derived plutonium has been intensively employed to 172 trace transportation of PPG-derived pollutions in the North Pacific Ocean and its marginal seas 173 including the ESC East China Sea and SYSSouth Yellow Sea. However, it is still unclear 
174 whether the PPG-derived pollution has entered to the YSYellow Sea, especially the NYS due to 175 lack of information on $\mathrm{Pu}$ isotopic compositions in this area.

176 As presented in Table A.S1, A.S2 (Supporting Supplementary materialinformation) and 177 depicted in Figure 2, the measured ${ }^{240} \mathrm{Pu} /{ }^{239} \mathrm{Pu}$ atomic ratios ranged from 0.175 to 0.190 with an 178 average of $0.184 \pm 0.005$ in all surface sediment samples. In the two sediment soil cores, $179{ }^{240} \mathrm{Pu} /{ }^{239} \mathrm{Pu}$ atomic ratios varied from 0.164 to 0.233 with an average of $0.194 \pm 0.02$ in NYSC18001 core, and from 0.163 to 0.206 with an average of $0.185 \pm 0.011$ in NYSC-02 core, which were 181 relative constant and similar to those determined in surface sediments. It is clear that the atomic 182 ratios of ${ }^{240} \mathrm{Pu} /{ }^{239} \mathrm{Pu}$ obtained in all sediment samples agreed very well with the average value of $183 \sim 0.18$ for the global atmospheric fallout, as well as with our previous reported values $(\sim 0.18)$ in 184 soils collected from Liaodong Bay coastal regions_Xu et al., 2013), ${ }^{31,33-34}$ which are quite close 185 to the present study area. Similar ${ }^{240} \mathrm{Pu} /{ }^{239} \mathrm{Pu}$ atomic ratios have also been reported in a sediment 186 core from the Lake Sihailongwan $\left(42.29^{\circ} \mathrm{N}, 126.6^{\circ} \mathrm{E}\right.$ ) (Wu et al., 2010), ${ }^{11}$ which is also located 187 in the northeast China and not very far $(<400 \mathrm{~km})$ from our study area. Combined these results 188 with our previous conclusion regarding $\mathrm{Pu}$ isotopes in soils of northeast China that the major 189 source of $\mathrm{Pu}$ in northeast China is the global atmospheric fallout, and any other possible 190 contributions should be very small, Pu isotopes in the sediments collected from the present study 191 area should be also mainly from the global atmospheric fallout.

192 It is well known that several NWTs have been conducted in the North Korea in the past ten 193 years. However, $\mathrm{Pu}$ is a refractory element and is not easily to be released to the atmosphere 194 during underground NWT, thus contributions of Pu from the NWTs in North Korea should be 195 negligible in spite of the short distance between the North Korea and our study area. Plutonium 196 released from the Fukushima Daiichi Nuclear Power Plant (FDNPP) accident might have 
197 potential impact on the surrounding areas including the YSYellow Sea. Since-However, the 198 FDNPP-derived $\mathrm{Pu}$ has been reported to have much higher ${ }^{240} \mathrm{Pu} /{ }^{239} \mathrm{Pu}$ atomic ratios $(0.303$ to 1990.381330 ) (Zheng et al., 2012) ${ }^{44-45}$ than the measured values in present studied sediments 200 collected in 2017, and some other reports (Bu et al., 2014; Hain et al., 2017; Oikawa et al., 2015;) 201 have also indicated that the influence of the FDNPP-diverved $\mathrm{Pu}$ to the marine environment 202 would be limited. -Thus it is reasonable to believe that the contribution from the FDNPP-source $203 \mathrm{Pu}$ to the total Pu inventory in our study area is negligible.

204 Numbers_of studies have reported that the close-in fallout Pu from the PPG has been 205 transported from the Marshall lands through the North Equatorial Current followed by the 206 Kuroshio Current and its extensions to the SCS-South China Sea and ESCEast China Sea (Liu et 207 al., 2011; Wang et al., 2005; Wang et al., 2017; Wu et al., 2014).$^{19,24,26-27}$ Significant higher $208{ }^{240} \mathrm{Pu} /{ }^{239} \mathrm{Pu}$ atomic ratios $(>0.20)$ were usually observed in surface sediments or bottom layers of 209 sediment cores in these marginal seas due to the contributions of PPG-sourced Pu with high $210{ }^{240} \mathrm{Pu} /{ }^{239} \mathrm{Pu}$ atomic ratios of $0.30-0.36$. But this is not the case in our study area, since no 211 abnormal higher ratios of ${ }^{240} \mathrm{Pu} /{ }^{239} \mathrm{Pu}$ were observed in both surface sediment samples and 212 bottom layers of the two sediment cores. This indicates at least that our study area did not receive 213 any PPG derived Pu from either the early direct close-in fallout or oceanic current transportation. 214 Although earlier studies regarding Pu in surface seawater samples from the central YS-Yellow 215 Sea and SYS-South Yellow Sea has shown some PPG-sourced Pu signals in surface seawater 216 with relative higher ratios (0.18-0.33 with an average of 0.23 ) (Kim et al., 2004), ${ }^{46}$ the impact of 217 the PPG close-in fallout Pu on the Yellow SeaS is still doubtful. Liu et al. (2013) ${ }^{25}$ studied the $218 \mathrm{Pu}$ isotopes in the North Jiangsu tidal flats of the YS-Yellow Sea and they concluded that the 219 tidal flats did receive mainly global fallout Pu but no PPG-derived Pu in any pathways, which 
220 are similar as our conclusions for the northern NYS. Therefore, the influence of the PPG-derived

221 Pu on the YSYellow Sea, especially the NYS might be very limited.

222 All above results suggested that the global atmospheric fallout is the major source of $\mathrm{Pu}$ in

223 the northern NYS, and any other possible contributions such as releases from NWTs of the North

224 Korea, the FDNPP accident, as well as early direct deposition or later oceanic current

225 transportation of PPG derived Pu are negligible. Since Feb. 2013, the Hongyanhe NPP has

226 started in operation of four units successively. The measured $\mathrm{Pu}$ isotopic composition in this

227 work will serve as a reference data for the future monitoring and assessment of environmental

228 impact of this NPP.

$229 \quad 3.2$ Spatial distribution of Pu isotopes in surface sediments in the northern NYS

230 The ${ }^{239+240} \mathrm{Pu}$ activities in surface sediments collected along the southeast coast of the Liaodong

231 Peninsula in the NYS are presented in Table A.S1 and Figure 3. A large variation of ${ }^{239+240} \mathrm{Pu}$ 232 concentrations from 0.022 to $0.515 \mathrm{mBq} / \mathrm{g}$ with an average of $0.122 \pm 0.021 \mathrm{mBq} / \mathrm{g}(n=10)$ was

233 observed in these sediment samples (Figure 2). Such ${ }^{239+240} \mathrm{Pu}$ activity levels are comparable to

234 the reported values observed in the NYS $(0.045$ to $0.901 \mathrm{mBq} / \mathrm{g}$ ) (Hong et al., 2006; Nagaya \& 235 Nakamura,1992) ${ }^{15,21}$ and the ESC East China Sea $(0.048-0.759 \mathrm{mBq} / \mathrm{g})$ (Liu et al., 2011; Wang

236 et al., 2017). ${ }^{24,27}$ It can be observed from the Figure 3 that the ${ }^{239+240} \mathrm{Pu}$ concentrations generally 237 show a westwards increasing trend along the coast with the highest values near the northeast cost 238 of Dalian Bay, which is similar to the direction of the LCC.

239 The distribution of $\mathrm{Pu}$ concentrations in surface sediments might be influenced by many 240 factors such as organic matter and particle size of the sediment, coastal currents and riverine 241 input. Since the differences of organic matter content in the surface sediments excluding the 242 surface sample of the NYSC-02 sediment core are very small, the influence of the organic matter 
243 contents on the ${ }^{239+240} \mathrm{Pu}$ activities was not significant.-_It has been reported byBased on the

244 analysis of the rare earth element compositions of the surface sediments in the southeast coastal

245 area of the Liaodong Peninsula, Chen et al.(2013) ${ }^{28}$ have reported that after re-suspension and

246 transportation by the LCC, the Yalu River-derived fine-grained sediments were re-deposited in

247 water depth of $20-40 \mathrm{~m}$ in the area, where is $180-300 \mathrm{~km}$ away from the Yalu River mouth and

248 extends along the southeast coast of the Liaodong Peninsula between the northeast of Dalian Bay

249 and southwest of the Changshan Islands_(as shown in Figure 1). It is obvious that the two

250 sampling sites of SS05 and SS06 in this study are just located in the reported Yalu River-derived

251 fine-grained deposition region. Our previous results-Researches regarding the association of $\mathrm{Pu}$

252 isotopes with natural soil particles have proved that $\mathrm{Pu}$ isotopes tend to associate with finer

253 particles due to their bigger specific surface areas_(Xu et al., 2017). ${ }^{34}$ Therefore, significant

254 higher ${ }^{239+240} \mathrm{Pu}$ activities in the sampling sites SS05 and SS06 are more likely to be attributed to

255 their much smaller particle sizes (SS05 and SS06 with mean grain sizes of 3.2 and $2.4 \mu \mathrm{m}$

256 respectively)., although there was no direct linear correlation between mean grain sizes and

$257{ }^{239+240} \mathrm{Pu}$ activities in all surface sediments. The lowest $\mathrm{Pu}$ concentrations in the east part of the

258 study area might be in relation to the dilution of Pu-depleted river-borne sediments from the

259 Yalu River and Dayang River. While in the most west two sampling sites SS07 and SS08, which

260 are close to the Bohai Strait, their very low ${ }^{239+240} \mathrm{Pu}$ concentrations $(0.025$ and $0.040 \mathrm{mBq} / \mathrm{g})$ are

261 likely to be related to the interaction influence of the YSWC and YSCC. Hence, the transport of

262 coastal currents and sediment dynamics of fine-particles should play an important role in

263 controlling the spatial distribution of Pu isotopes in the northern NYS.

$264 \quad 3.3$ Temporal variations of Pu isotopes in the northern NYS 
265 The vertical profiles of ${ }^{239+240} \mathrm{Pu}$ activities in the two sediment cores are illustrated in Figure 4 266 and summarized in Table $\underline{\mathrm{A} . \mathrm{S} 2}$. The ${ }^{239+240} \mathrm{Pu}$ concentrations in the NYSC-01 sediment core 267 ranged from 0.006 to $0.251 \mathrm{mBq} / \mathrm{g}$ with an average of $0.141 \pm 0.061 \mathrm{mBq} / \mathrm{g}$, which are nearly 2 268 times lower than those in the NYSC-02 sediment core with a range of 0.002 to $0.576 \mathrm{mBq} / \mathrm{g}$ and 269 an average of $0.231 \pm 0.052 \mathrm{mBq} / \mathrm{g}$. This difference may be partly attributed to the effect of 270 particle size on the association of $\mathrm{Pu}$ with sediments. Considering that the NYSC-02 sampling 271 site with water depth of $20 \mathrm{~m}$ and fine size grain sediment of a mean grain size of $6.04 \mu \mathrm{m}$ is 272 located in the fine grained deposition region, higher Pu concentrations would be expected at this 273 site due to the stronger adsorption of plutonium by finer grain sediments. While the NYSC-01 274 sampling site with water depth of $10 \mathrm{~m}$ and relative coarser grain sediment of a mean grain size 275 of $6.82 \mu \mathrm{m}$ is located in the pathway of the LCC and much closer to the mouth of the Yalu River. 276 In the near shore zone, due to the strong hydrodynamic conditions, fine particles adsorbed more $277 \mathrm{Pu}$ isotopes are easily re-suspended in water column and further transported westwards through 278 the LCC, but coarse sediments with weaker adsorption of Pu isotopes were deposited locally, 279 resulting in the lower $\mathrm{Pu}$ concentrations in the NYSC-01 site. Moreover, the difference in 280 organic matter contents may also be one reason of different $\mathrm{Pu}$ concentrations in these two 281 sediment cores. Although linear regression analyses showed that there was no obvious 282 correlation between $\mathrm{Pu}$ concentrations in the NYSC-02 core and its relative constant organic 283 matter contents from the top to the bottom layers. While, the relationship between the organic 284 matter contents and $\mathrm{Pu}$ concentrations in the NYSC-01 core is significant $\left(r^{2}=0.64, p<0.05\right)$ as 285 shown in Figure A.S1. The organic matter content in the NYSC-02 (with an average of 7.32\%) 286 was much higher than that in the NYSC-01 core (average of 5.84\%). 
It can be observed from the Figure 4 that ${ }^{239+240} \mathrm{Pu}$ activities in both sediment cores showed

288 unambiguous maximum values and background levels. Based on the previous discussions that $\mathrm{Pu}$

289 isotopes in the study area are mainly from the global fallout and the well-defined global fallout

290 history, it is reasonable to relate the pronounced peaks to the historical global fallout maximums

291 in 1963 and the positions of background values to the 1952 horizons (onset fallout). Using the

2921963 horizon as a discrete time marker, we obtained similar mean sedimentation rate of 0.46

$293 \mathrm{~cm} / \mathrm{yr}$ for both sediment cores, but two different sediment accumulation rates of $0.61 \mathrm{~g} / \mathrm{cm}^{2} \cdot \mathrm{yr}$ for

294 the NYSC-01 core and $0.52 \mathrm{~g} / \mathrm{cm}^{2} \cdot \mathrm{yr}$ for the NYSC-02 core, respectively. While taking the 1952

295 horizons as a chronological marker for sediment dating, the mean sedimentation rates and mean

296 sediment accumulation rates were calculated to be $0 . \underline{6057}$ and $0.51 \mathrm{~cm} / \mathrm{yr}$ and $0.7 \underline{74}$ and 0.56

$297 \mathrm{~g} / \mathrm{cm}^{2} \cdot \mathrm{yr}$ respectively for the NYSC-01 and NYSC-02 cores, which are slightly higher but still

298 comparable to the results obtained from the 1963 marker. The difference between the results

299 obtained from the two time markers has been evaluated using a statistic $t$-test $\left(t_{\text {stat }}=-\underline{3.18} 1.34<t_{\text {crit }}\right.$

300 for $n=4$ ), which suggests that both 1963 and 1952 horizons are valid chronological markers for

301 the sediment dating in the present study area. In fact, our results are also within the range of the

302 results $\left(0.06-1.18 \mathrm{~g} / \mathrm{cm}^{2} \cdot \mathrm{yr}\right)$ reported by Qi et al. $(2004)^{47} \mathrm{using}{ }^{210} \mathrm{~Pb}_{\text {ex }}$ dating method regarding

303 the sediment cores in the NYS. The mean sediment accumulation rates obtained in the NYSC-01

304 core from the both time markers were obviously higher than those in the NYSC-02 core,

305 indicating that the sedimentary environment in the latter sampling site are relatively stable in the

306 past decades. This was reasonable and coincided well with the previous discussions.

307 Further insight into the temporal variation of $\mathrm{Pu}$ isotopes in the northern NYS was provided

308 by the distribution patterns of $\mathrm{Pu}$ concentrations from the surface to the 1963 horizon in both

309 sediment cores. According to the report of UNSCEAR $(2000),{ }^{5}$ the temporal variation of the 
310 annual global fallout deposition of ${ }^{137} \mathrm{Cs}$ in northern hemisphere (Figure 5) showed a maximum 311 in 1963 and then significantly decreased to a low level especially after 1980 . The historical 312 pattern of the global fallout deposition of ${ }^{239+240} \mathrm{Pu}$ is believed to be similar. According to the 313 estimation of Nakano and Povinec (2003), ${ }^{48}$ the annual global fallout deposition of ${ }^{239+240} \mathrm{Pu}$ in 314 marine environment was also found to be maximal in 1963 and then decrease dramatically. 315 While the direct deposition of the global fallout $\mathrm{Pu}$ was recorded in undisturbed lakes, as 316 depicted in the Figure 5, typical ${ }^{239+240} \mathrm{Pu}$ concentration peaks corresponding to the maximum 317 deposition of 1963-1964 and followed by sustained declines were observed in lake Qinhai and 318 lake Hongfeng which are located respectively in northwest and southwest of China_Wu et al.., 319 2011; Zheng et al., 2008). $\cdot{ }^{10,12}$ However, A constant high ${ }^{239+240} \mathrm{Pu}$ activities were observed in the 320 sediment core NYSC-01 corresponding to the period of 1979- 2009 (Figure 4 and 5), and 321 significant higher ${ }^{239+240} \mathrm{Pu}$ activities were observed in the sediment core NYSC-02 from the 322 mass depth of $15.13 \mathrm{~g} / \mathrm{cm}^{2}$ to $5.99 \mathrm{~g} / \mathrm{cm}^{2}$ corresponding to the period of 1988 to 2005 . This 323 indicates that besides the direct atmospheric fallout, there are other inputs of plutonium to the 324 sediment, especially after 1980 . The riverine input sediments which are mainly sourced from the 325 soil erosion in the river catchments should be the main source of the excessive plutonium in the 326 sediment cores. Plutonium in the riverine sediments in the northeast China should also originate 327 from the global fallout according to the previous studies based on the constant ${ }^{240} \mathrm{Pu} /{ }^{239} \mathrm{Pu}$ ratios 328 in the whole soil and sediment cores (Wu et al., 2010; Xu et al., 2013). ${ }^{11,31-34}$ In conclusion, the 329 unusual distributions of global fallout $\mathrm{Pu}$ in the upper layers of the two sediment cores is 330 attributed to the riverine input sediments over time, time and this will be further discussed in the 331 next section.

332 3.4 Contribution of $\mathrm{Pu}$ from riverine input and its response to catchment environment 
Inventory of ${ }^{239+240} \mathrm{Pu}$ in sediment cores can help to interpret the source function and the

334 transport of $\mathrm{Pu}$, thus providing a useful indicator for assessing the sedimentary process in the

335 marine environment. In this study, how riverine input sediment influenced the global fallout $\mathrm{Pu}$

336 depositions in the sediments could be further deduced from the inventories of $\mathrm{Pu}$ in the two

337 sediment cores. The total Pu inventories were estimated to be $92.5 \pm 1.6 \mathrm{~Bq} / \mathrm{m}^{2}$ for the NYSC-01

338 core and $108.8 \pm 1.2 \mathrm{~Bq} / \mathrm{m}^{2}$ for the NYSC-02 core, respectively. These values are nearly twice

339 the average values of global atmospheric fallout $\left(42-58 \mathrm{~Bq} / \mathrm{m}^{2}\right)$ expected at the similar latitudinal

340 belts of $30-50^{\circ} \mathrm{N}$ (UNSCEAR, 1982; 2000), ${ }^{5,49}$ and also generally higher than those (55.5-90

$341 \mathrm{~Bq} / \mathrm{m}^{2}$, Table $\mathrm{A}$. \$3) obtained from the undisturbed soil and sediment sampling sites with similar

342 average annual precipitations $(600-800 \mathrm{~mm})$ at the similar latitude of $\sim 39^{\circ} \mathrm{N}$ worldwide (Hardy

343 et al., 1973; Wu et al., 2010; Xu et al., 2013; 2015), ${ }^{11,31,33,50}$ which are believed to receive solely

344 global fallout $\mathrm{Pu}$. This indicates that besides the direct deposition from the global fallout, riverine

345 input should contribute to some $\mathrm{Pu}$ depositions in the study area. Since the integrated global

346 fallout values of 42 and $58.1 \mathrm{~Bq} / \mathrm{m}^{2}$ respectively for $30-40^{\circ} \mathrm{N}$ and $40-50^{\circ} \mathrm{N}$ published by

347 UNSEAR_(1982; 2000) ${ }^{5,49}$ were average values without considering the influence of annual 348 precipitation on $\mathrm{Pu}$ fallout in specific sampling sites, they may not indeed represent the direct

349 deposition of global fallout in the study area. Comparing global fallout $\mathrm{Pu}$ inventory data

350 obtained from undisturbed soil and sediment cores with similar annual precipitation and latitudes

351 as the study area $\left(\sim 39^{\circ} \mathrm{N}\right)$, an average value of $78.9 \mathrm{~Bq} / \mathrm{m}^{2}$ (Figure 6-a) was believed to be more

352 close to the real direct deposition of global fallout $\mathrm{Pu}$ in the study area, and thus is taken into

353 account in the calculation of the contributions of $\mathrm{Pu}$ from both direct deposition and riverine 354 input. 
The calculation results showed that the riverine input $\mathrm{Pu}$ contributes to about $15 \%$ and $27 \%$

356 of the total Pu inventories in the NYSC-01 and NYSC-02 cores, respectively (Figure 6-b). Since

357 plutonium has high affinity to particle and can be easily adsorbed to soil particles after

358 deposition on the earth surface, contributions of $\mathrm{Pu}$ from the riverine input should directly reflect

359 the degree of soil erosion in river catchments. In order to evaluate whether this reflection is

360 reliable, we did a comparative study between the Yangtze River and the Yalu River catchments.

361 Based on the previous published Pu data from the sediment cores of SC07 and SC18 collected in

362 the Yangtze River estuary(Liu et al., 2011; Pan et al., 2011),23-24 the contribution of Pu from the

363 Yangtze River input to the total global fallout $\mathrm{Pu}$ inventory in the Yangtze River estuary was

364 estimated to be $77-80 \%$ as shown in Figure 6-b (note that the total global fallout Pu inventories

365 in the SC07 and SC08 cores were 244 and $217 \mathrm{~Bq} / \mathrm{m}^{2}$, respectively, corresponding to the total $\mathrm{Pu}$

366 subtracted the PPG-derived $\mathrm{Pu}$, and the direct deposition of global fallout for the Yangtze River

367 estuary was estimated to be $49.8 \mathrm{~Bq} / \mathrm{m}^{2}$ based on the data reported by Dong et al. $\left.(2010)^{51}\right)$.

368 Obviously, the riverine $\mathrm{Pu}$ contributions in the Yangtze River estuary are nearly 3 to 4 times

369 higher than that in our study area, implying that the status of soil erosion in the Yangtze River's

370 catchments might be much more serious than that of the Yalu River and other rivers in northeast

371 China.

372 The above conclusion was further supported by a comprehensive comparison of the

373 catchment area, average annual runoff and sediment discharge between these rivers as shown in

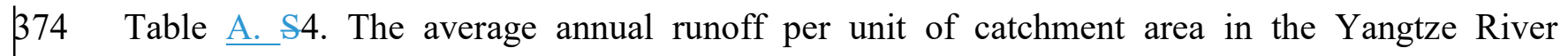

375 catchment is about 1.2 times higher than that in the three major river catchments of the study

376 area, which is reasonable and agrees with the relatively higher precipitation in the Yangtze River

377 catchment $(\sim 1000 \mathrm{~mm})$ compared to that in the Yalu River catchment $(\sim 800 \mathrm{~mm})$. While the 
378 average annual sediment discharge of the Yangtze River was estimated to be 7.5 times the total

379 average annual sediment discharges of the three rivers in the study area, indicating the soil

380 erosion amount in the Yangtze River catchment should be much larger than that in the river

381 catchments of northeast China, which is consistent with the conclusion deduced from the

382 contributions of riverine Pu. The great difference of soil erosion between Yalu River's catchment

383 in the northeast China and Yangtze River's drainage basin in the central China should be mainly

384 attributed to the relatively higher forest coverage and less vegetation breakage by human

385 activities in the northeast China compared to the central China.

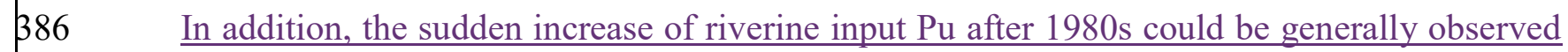

387 in both sediments cores as shown in Figure 5, which might provide more insights on evaluation

388 of the catchment environment in the northeast China. That riverine input $\mathrm{Pu}$ increased rapidly

389 after 1980s should reflect this might results from the increase of soil erosion degree in the

390 northeast China at the same period. , which could be mainly attributed to land use and cover

391 ehange (LUCC) in the area.According to the studies of Li et al. (2010), due to the increased

392 human activities, the land use changed intensively in the northeast China from the 1980s to 2000.

393 During this period, cropland increased substantially, while woodland, grassland, water body and

394 marsh decreased sharply, and among all land use types, paddy fields increased

395 fastestsignificantly (by $20 \%$ ), conversely, grassland and marsh decreased rapidly fastest, by $17 \%$

396 and $12 \%$, respectively. Such land use and cover change should-result in much more soil loss in

397 the northeast China.

398 4. Conclusions

399 The present work for the first time investigated the sedimentary records of ${ }^{239} \mathrm{Pu}$ and ${ }^{240} \mathrm{Pu}$ in 400 the NYS. From isotopic compositions of the two Pu isotopes in surface and core sediments, we 
401 concluded that plutonium in the northern NYS is mainly from the global atmospheric fallout 402 without any significant contributions from NWTs of the North Korea, the FDNPP accident, as 403 well as PPG sourced Pu. From the depth profiles of ${ }^{239+240} \mathrm{Pu}$ activities with easily observed onset 404 and fallout peaks in the two sediment cores, ${ }^{239+240} \mathrm{Pu}$ was found to be a useful time marker in 405 sediments of the northern NYS. The riverine $\mathrm{Pu}$ was estimated to contribute $15-27 \%$ to the total 406 global fallout $\mathrm{Pu}$ inventory in the study area, which are much lower than that in the Yangtze 407 River estuary, indicating the soil erosion in the northeast China was much less than that in the 408 Yangtze River's drainage basin. The sudden increase of riverine input Pu after 1980s reflected 409 the increased soil erosion degree caused by the land use and cover change due to the increased

410 human activities in the northeast China. In addition, the activity level and the atomic ratio of $\mathrm{Pu}$ 411 isotopes reported in this work can serve as a baseline for future environmental monitoring and 412 risk assessment related to the operation of Hongyanhe NPP or any other potential nuclear 413 activities.

\section{Acknowledgments}

415 This work was jointly supported by the National Natural Science Foundation of China 416 (41671466, 41501286, and 41576043), Natural Science Foundation of Jiangsu Province 417 (BK20150578) and the Fundamental Research Funds for the Central Universities 418 (020914380010, 020914380001). Authors thank Dr. Zhongtang Wang and Wenna Huang for 419 their supports to sample analysis, as well as Dr. Zuo Wang for his help with map drawing.

420 Appendix A. Supplementary material

\section{Supplementary material related to this article can be found online at}

\section{$422 \quad$ References}


423 Bao, Y.E., Du, Z.X., 1999. Annals of Chinese Bay (Volume 3): Estuaries (Liaoning). China 424 Ocean Press, Beijing. (in Chinese).

425 Buesseler, K.O., 1997. The isotopic signature of fallout plutonium in the North Pacific. J. 426 Environ. Radioact. $36(1), 69-83$.

427 Buesseler, K.O., Sholkovitz, E.R., 1987. The geochemistry of fallout plutonium in the North 428 Atlantic: II. ${ }^{240} \mathrm{Pu} /{ }^{239} \mathrm{Pu}$ ratios and their significance. Geochim. Cosmochim. Acta. 51, 2623429 2637.

430 Bu, W.T., Fukuda, M., Zheng, J., Aono, T., Ishimaru, T., Kanda, J., Yang, G.S., Tagami, K., 431 Uchida, S., Guo, Q.J., Yamada, M., 2014. Release of Pu Isotopes from the Fukushima Daiichi Nuclear Power Plant Accident to the Marine Environment Was Negligible. Environ. Sci. Technol. 48, 9070-9078.

Chen, X.H., Li, T.G., Zhang, X.H., Li, R.H., 2013. A Holocene Yalu River-derived fine-grained deposit in the southeast coastal area of the Liaodong Peninsula. Chin. J. Oceanol. Limn. 31(3), 636-647.

Corcho-Alvarado, J.A., Diaz-Asencio, M., Froidevaux, P., Bochud, F., Alonso-Hernández, C.M., Sanchez-Cabeza, J.A., 2014. Dating young Holocene coastal sediments in tropical regions: use of fallout ${ }^{239,240} \mathrm{Pu}$ as alternative chronostratigraphic marker. Quat. Geochronol. 22, 1-10.

Dong W., Tims, S.G., Fifield, L.K., Guo, Q. J., 2010. Concentration and characterization of plutonium in soils of Hubei in central China. J. Environ. Radioact. 101, 29-32.

Gatsaud, J., Povinec, P.P., Aoyama, M., Hirose, K., Sanchez-Cabeza J.A., Levy, I., Roos, P., Eriksson, M., Bosc, E., Rezzoug, S., 2011. Transport and scavenging of Pu in surface waters of the Southern Hemisphere Oceans. Prog. Oceanogr. 89, 92-100. 
Hain, K., Faestermann, T., Fimiani, L., Golser, R., Gómez-Guzmán, J.M., Korschinek, G., Kortmann, F., von Gostomski, C.L., Ludwig, P., Steier, P., Tazoe, H., Yamada, M., 2017. Plutonium Isotopes $\left({ }^{239-241} \mathrm{Pu}\right)$ Dissolved in Pacific Ocean Waters Detected by Accelerator Mass Spectrometry: No Effects of the Fukushima Accident Observed. Environ. Sci. Technol. $51,2031-2037$.

Hancock, G.J., Leslie, C., Everett, S.E., Tims, S.G., Brunskill, G.J., Haese, R., 2011. Plutonium as a chronomarker in Australian and New Zealand sediments: a comparison with ${ }^{137} \mathrm{Cs}$. J. Environ. Radioact. 102, 919-929.

Hardy, E.P., Krey, P.W., Volchok, H.L., 1973. Global inventory and distribution of fallout plutonium. Nature. 241, 444-445.

Hirose, K., Igarashi, Y., Aoyama, M., Miyao, T., 2001. Long-term trends of plutonium fallout observed in Japan. In Plutonium in the Environment; Kudo, A., Ed.; Elsevier Science: Amsterdam, pp 251-266.

Hong, G.H., Chung, C.S., Lee, S.H., Kim, S.H., Baskaran, M., Lee, H.M., Kim, Y.I., Yang, D.B., Kim, C.K., 2006. Artificial radionuclides in the Yellow Sea: inputs and redistribution. Radioactivity in the Environment-International Conference on Isotopes in Environmental Studies. 8, 96-133.

Hong, G.H., Hamilton, T.F., Baskaran, M., Kenna, T.C., 2011. Applications of anthropogenic radionuclides as tracers to investigate marine environmental processes. In Handbook of Environmental Isotope Geochemistry, Advances in Isotope Geochemistry; Baskaran, M., Ed.; Springer-Verlag: Berlin Heidelberg, pp 367-394.

Huh, C.A., Su, C.C., 1999. Sedimentation dynamics in the East China Sea elucidated from ${ }^{210} \mathrm{~Pb}$, ${ }^{137} \mathrm{Cs}$, and ${ }^{239,240} \mathrm{Pu}$. Mar. Geol. 160, 183-196. 
468

469

470

471

472

473

474

475

476

477

478

479

480

481

482

483

484

485

486

487

488

489

Kelley, J.M., Bond, L.A., Beasley, T.M., 1999. Global distribution of Pu isotopes and ${ }^{237}$ Np. Sci. Total Environ. 237/238, 483-500.

Ketterer, M.E., Hafer, K.M., Jones, V.J., Appleby, P.G., 2004. Rapid dating of recent sediments in Loch Ness: inductively coupled plasma mass spectrometric measurements of global fallout plutonium. Sci. Total Environ. 322, 221-229.

Koide, M., Bertine, K.K., Chow, T.J., Goldberg, E.D., 1985. The ${ }^{240} \mathrm{Pu} /{ }^{239} \mathrm{Pu}$ ratio, a potential geochronometer. Earth Planet. Sci. Lett. 72, 1-8.

Kim, C.K., Kim, C.S., Chang, B.U., Choi, S.W., Chung, C.S., Hong, G.H., Hirose, K., Igarashi, Y., 2004. Plutonium isotopes in seas around the Korean Peninsula. Sci. Total Environ. 318, 197-209.

Lee, M.H., Clark, S.B., 2005. Activities of Pu and Am isotopes and isotopic ratios in a soil contaminated by weapons grade plutonium. Environ. Sci. Technol. 39, 5512-5516.

Lee, S.H., Gastaud, J., Povinec, P.P., Hong, G.H., Kim, S.H., Chung, C.S., Lee, K.W., Pettersson, H.B.L., 2003. Distribution of plutonium and americium in the marginal seas of the northwest Pacific Ocean. Deep-Sea Research Part II. 50, 2727-2750.

Li, X.Y., Zhao, G.M., Li, B.Y., 2010. Analysis of Changing Situation of Land Resources in Northeast China. Res. Soil Water Conserv. 17 (5), 68-74. (in Chinese).

Lindahl, P., Lee, S.H., Worsfold, P., Keith-Roach, M., 2010. Plutonium isotopes as tracers for ocean processes: A review. Mar. Environ. Res. 69, 73-84.

Liu, Z.Y., Zheng, J., Pan, S.M., Dong, W., Yamada, M., Aono, T., Guo, Q.J., 2011. Pu and ${ }^{137}$ Cs in the Yangtze River Estuary sediments: distribution and source identifi-cation. Environ. Sci. Technol. 45 (5), 1805-1811. 
Liu, Z.Y., Zheng, J., Pan, S.M., Gao, J.H., 2013. Anthropogenic plutonium in the North Jiangsu tidal flats of the Yellow Sea in China. Environ. Monit. Assess. 185, 6539-6551.

492 Muramatsu, Y., Rühm, W., Yoshida, S., Tagami, K., Uchida, S., Wirth, E., 2000. Concentrations 493 of ${ }^{239} \mathrm{Pu}$ and ${ }^{240} \mathrm{Pu}$ and their isotopic ratios determined by ICP-MS in soils collected from the 494 Chernobyl 30-km zone. Environ. Sci. Technol. 34, 2913-2917.

495 Muramatsu, Y., Hamilton, T., Uchida, S., Tagami, K., Yoshida, S., Robison, W., 2001. 496 Measurement of ${ }^{240} \mathrm{Pu} /{ }^{239} \mathrm{Pu}$ isotopic ratios in soils from the Marshall Islands using ICP-MS. 497 Sci. Total Environ. 278, 151-159.

498 Nagaya, Y., Nakamura, K., 1992. ${ }^{239,240} \mathrm{Pu}$ and ${ }^{137} \mathrm{Cs}$ in the east China and the Yellow seas. J. 499 Oceanogr. 48, 23-35.

500 Nakano, M., Povinec, P.P., 2003. Modelling the distribution of plutonium in the Pacific Ocean. J. $501 \quad$ Environ. Radioact. 69, 85-106.

502 Oikawa S., Watabe T., Takata H., Misonoo J., Kusakabe M. 2015. Plutonium isotopes and ${ }^{241}$ Am 503 in surface sediments off the coast of the Japanese islands before and soon after the 504 Fukushima Dai-ichi nuclear power plant accident. J. Radioanal. Nucl. Chem. 303, 1513$505 \quad 1518$.

506 Pan, S.M., Tims, S.G., Liu, X.Y., Fifield, L.K., $2011 .{ }^{137} \mathrm{Cs}$, ${ }^{239+240} \mathrm{Pu}$ concentrations and the 507 ${ }^{240} \mathrm{Pu} /{ }^{239} \mathrm{Pu}$ atom ratio in a sediment core from the sub-aqueous delta of Yangtze River estuary. J. Environ. Radioact. 102(10), 930-936.

Qi, J., Li, F.Y., Song, J.M., Gao, S., Wang, G.Z., Cheng, P., 2004. Sedimentation rate and flux of the North Yellow Sea. Marine Geology \& Quaternary Geology. 24(2), 9-14(in Chinese). 
511 Qiao, J.X., Hou, X.L., Roos, P., Miró, M., 2009. Rapid Determination of plutonium isotopes in 512 environmental samples using sequential injection extraction chromatography and detection 513 by inductively coupled plasma mass spectrometry. Anal. Chem. 81, 8185-8192.

514 State Oceanic Administration, 1998. Chinese Harbours and Embayments (Volume 14): 515 Important Esturaies. China Ocean Press, Beijing, pp 386-432 (in Chinese).

$516 \mathrm{Su}, \mathrm{CC}$., Huh, C.A., 2002. ${ }^{210} \mathrm{~Pb},{ }^{137} \mathrm{Cs}$, and ${ }^{239,240} \mathrm{Pu}$ in East China Sea sediments: Sources, 517 pathways and budgets of sediments and radionuclides. Mar. Geol. 183, 163-178.

518 UNSCEAR, 1982. Ionizing Radiation: Sources and Effects; United Nations Scientific Committee 519 on the Effects of Atomic Radiation Exposures to the Public from Man-made Sources of $520 \quad$ Radiation; United Nations: New York, pp 211.

521 UNSCEAR, 2000. Sources and effects of ionizing radiation. United Nations scientific committee 522 on the effects of atomic radiation exposures to the public from man-made sources of 523 radiation; United Nations, New York, pp 214-215.

524 Wang, J.L., Baskaran, M., Hou, X.L., Du, J.Z., Zhang, J., 2017. Historical changes in ${ }^{239} \mathrm{Pu}$ and 525

527 Wang, Z.L., Yamada, M., 2005. Plutonium activities and ${ }^{240} \mathrm{Pu} /{ }^{239} \mathrm{Pu}$ atom ratios in sediment 528 cores from the East China Sea and Okinawa Trough: Sources and inventories. Earth Planet. $529 \quad$ Sci. Lett. 233, 441-453.

530 Warneke, T., Croudace, I.W., Warwick, P.E., Taylor, R.N., 2002. A new ground-level fallout 531 record of uranium and plutonium isotopes for northern temperate latitudes. Earth Planet. Sci. 532 Lett. 203, 1047-1057. 
533 Wu, F.C., Zheng, J., Liao, H.Q., Yamada, M., 2010. Vertical distributions of plutonium and

$534 \quad{ }^{137} \mathrm{Cs}$ in lacustrine sediments in northwestern China: quantifying sediment accumulation 535 rates and source identifications. Environ. Sci. Technol. 44, 2911-2917.

536 Wu, F.C., Zheng, J., Liao, H.Q., Yamada, M., Wan, G.J., 2011. Anomalous plutonium isotopic 537 ratios in sediments of Lake Qinghai from the Qinghai-Tibetan Plateau, China. Environ. Sci. $538 \quad$ Technol. 45, 9188-9194.

539 Wu, J.W., Zheng, J., Dai, M.H., Huh, C.A., Chen, W., Tagami, K., Uchida, C., 2014. Isotopic 540 composition and distribution of plutonium in Northern South China Sea sediments revealed 541 continuous release and transport of $\mathrm{Pu}$ from the Marshall Islands. Environ. Sci. Technol. 48, $542 \quad 3136-3144$.

543 Xu, Y.H., Qiao, J.X., Hou X.L., Pan, S.M., 2013. Plutonium Isotopes in Soils from Northeast 544 China and Its Potential Application for Evaluation of Soil Erosion. Sci. Rep. 3, 3506; DOI: $545 \quad 10.1038 /$ SREP03506.

546 Xu, Y.H., Qiao, J.X., Hou X.L., Pan, S.M., Roos, P., 2014. Determination of Plutonium Isotopes $547 \quad\left({ }^{238} \mathrm{Pu},{ }^{239} \mathrm{Pu},{ }^{240} \mathrm{Pu}\right.$ and $\left.{ }^{241} \mathrm{Pu}\right)$ in Environmental Samples Using Radiochemical Separation 548 Combined with Radiometric and Mass Spectrometric Measurements. Talanta. 119, 590-595. 549 Xu, Y.H., Qiao, J.X., Pan, S.M., Hou, X.L., Roos, P., Cao, L.G., 2015. Plutonium as a tracer for 550 soil erosion assessment in Northeast China. Sci. Total Environ. 511, 176-185.

551 Xu, Y.H., Pan, S.M., Wu, M.M., Zhang, K.X., Hao, Y.P., 2017. Association of Plutonium 552 isotopes with natural soil particles of different size and comparison with ${ }^{137}$ Cs. Sci. Total $553 \quad$ Environ. 581-582, 541-549. 
554 Zheng, J., Tagami, K., Watanabe, S., Uchida, S., Aono, T., Ishii, N., Yoshida, S., Kubota, Y., 555 Fuma, S., Ihara, S., 2012. Isotopic evidence of plutonium release into the environment from 556 the Fukushima DNPP accident. Sci. Rep. 2, 304 DOI: 10.1038/srep00304.

557 Zheng, J., Wu, F.C., Yamada, M., Liao, H.Q., Liu, C.Q., Wan, G.J., 2008. Global fallout Pu 558 recorded in lacustrine sediments in Lake Hongfeng, SW China. Environ. Pollut. 152, 314$559 \quad 321$.

560 Zheng, J., Yamada, M., 2006. Plutonium isotopes in settling particles: Transport and scavenging 561 of $\mathrm{Pu}$ in the western northwest pacific. Environ. Sci. Technol. 40, 4103-4108.

\section{Figure captions}

564 Figure 1 a) Overview map of the Yellow Sea with the principal currents, plotted after Huh \& Su, 1999 and Su \& Huh, 2002. b) Detail of the Yellow Sea and its coasts with the location of the study area being highlighted by a red rectangle. c) Detailed sampling sites in the North Yellow Sea. The red oval dotted frame indicates the location of the Yalu River-derived clinoform according to Chen et al. (2013). YSWC: Yellow Sea Warm Current; YSCC: Yellow Sea Coastal Current; LCC: Liaonan Coastal Current; WKCC: West Korea Coastal

Figure 2 Distribution of ${ }^{240} \mathrm{Pu} /{ }^{239} \mathrm{Pu}$ atomic ratios in surface sediments and sediment cores in the

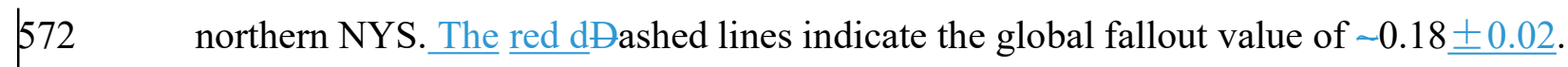

573 Figure 3 Distribution of the ${ }^{239+240} \mathrm{Pu}$ activities in all surface sediments (including the surface 574 layer $(0-2 \mathrm{~cm})$ of the two sediment cores NYSC-01 and NYSC-02) along the southeast coast 575 of the Liaodong Peninsula. The red oval dotted frame indicates the location of the Yalu $576 \quad$ River-derived clinoform according to Chen et al. (2013). 
577 Figure 4 Vertical profiles of ${ }^{239+240} \mathrm{Pu}$ activities in sediment cores collected from the northern $578 \quad$ NYS.

579 Figure 5 Abundance of annual deposition of ${ }^{137} \mathrm{Cs}$ in northern hemisphere and abundance of 580 deposition of ${ }^{239+240} \mathrm{Pu}$ in each layer of sediments. The annual deposition data of ${ }^{137} \mathrm{Cs}$ in 581 northern hemisphere were cited from the UNSCEAR (2000). ${ }^{5}$ Data of Pu in Lake Hongfeng 582 and Qinghai were respectively cited from Zheng et al. $(2008)^{10}$ and $\mathrm{Wu}$ et al. $(2011)^{11}$ and mainly originated from the global fallout direct deposition.

584 Figure 6 a) Comparison of ${ }^{239+240} \mathrm{Pu}$ inventories between the northern NYS and the Yangtze 585 River estuary. ${ }^{239+240} \mathrm{Pu}$ inventories for $\sim 31^{\circ} \mathrm{N}$ and $\sim 39^{\circ} \mathrm{N}$ were calculated as the averages of 586 the data reported respectively by Dong et al. $(2010)^{51}$ and by Xu et al. $(2013,2015){ }^{31,33}$-and $587 \quad$ Hardy et al.(1973) ${ }^{50}$ as shown in Table A.\$3. b) Comparison of the relative contributions of $588 \quad \mathrm{Pu}$ from the direct global fallout deposition and riverine input between the northern NYS and 589 the Yangtze River estuary.

$596 \quad$ Figure 1 


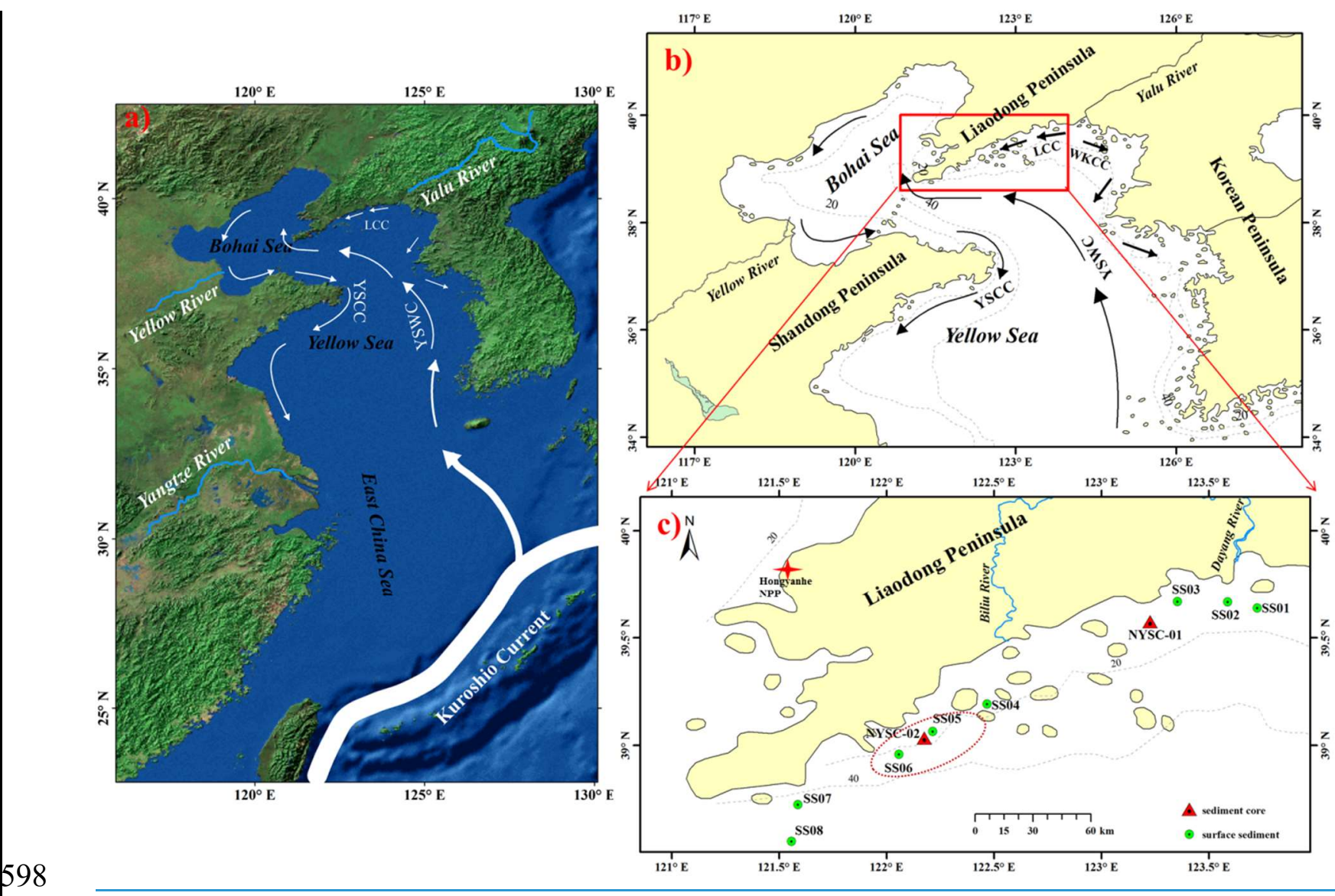

599

600 Figure 2 


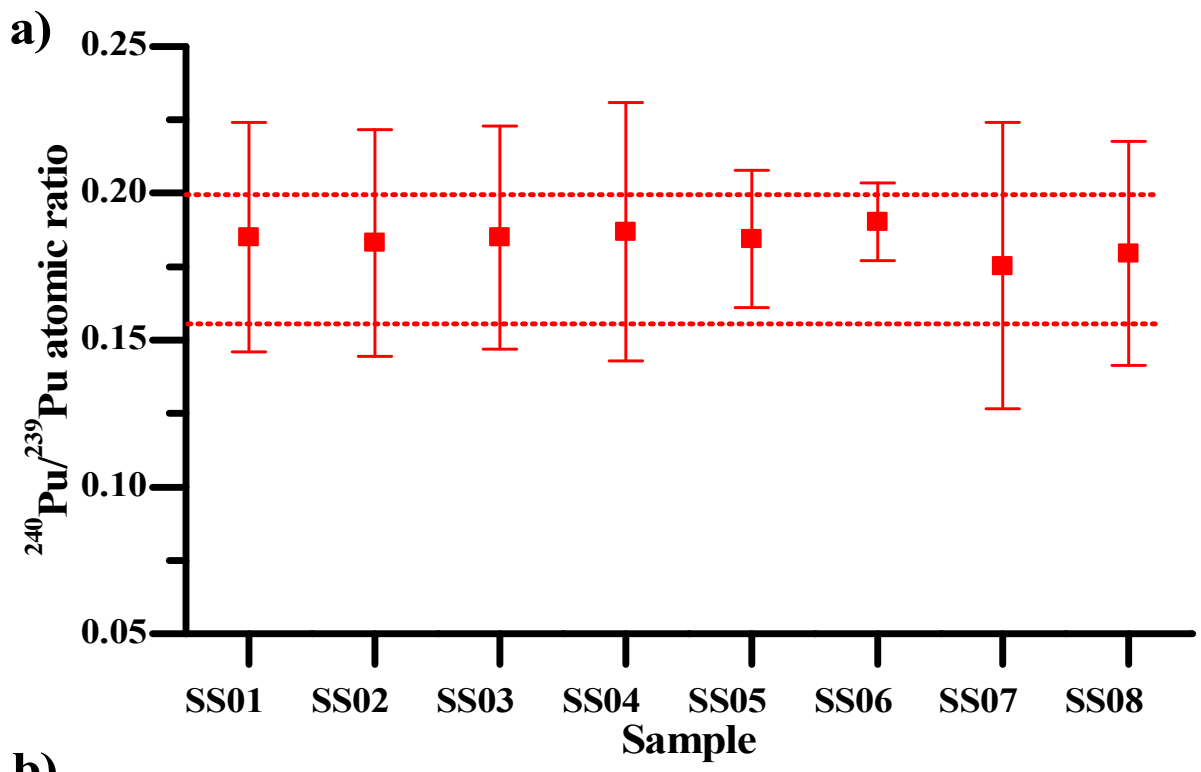

601

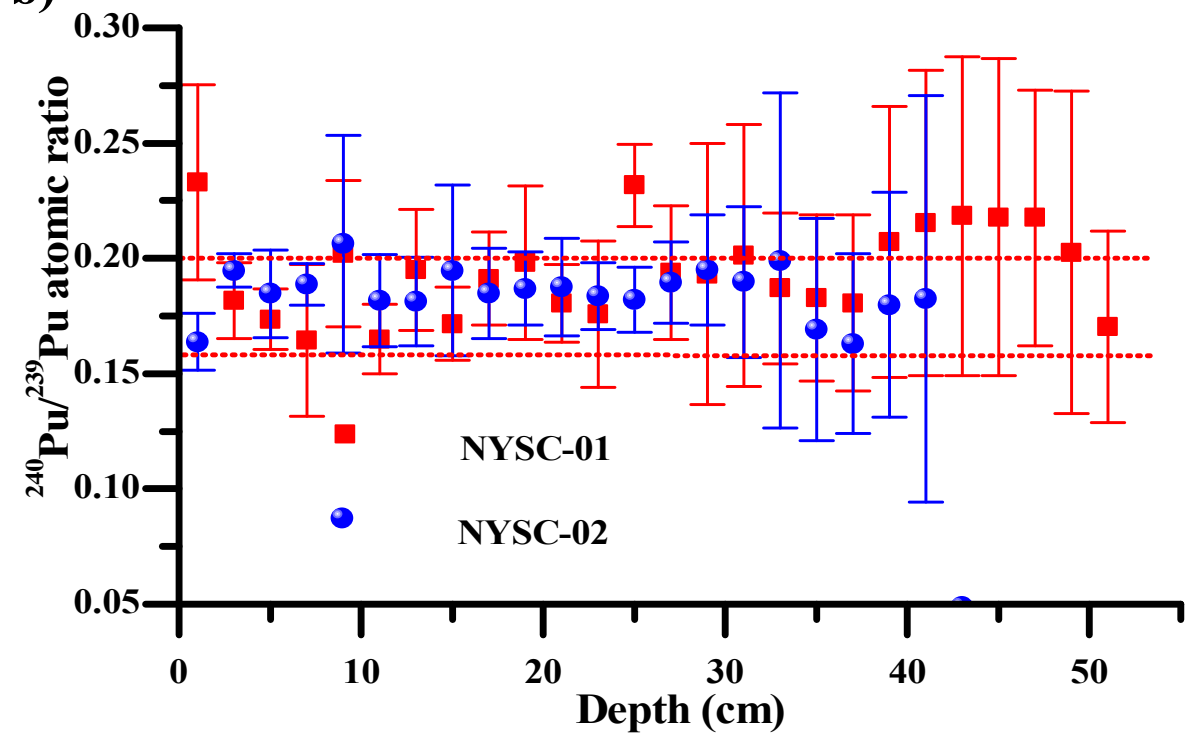

602

603 Figure 3 


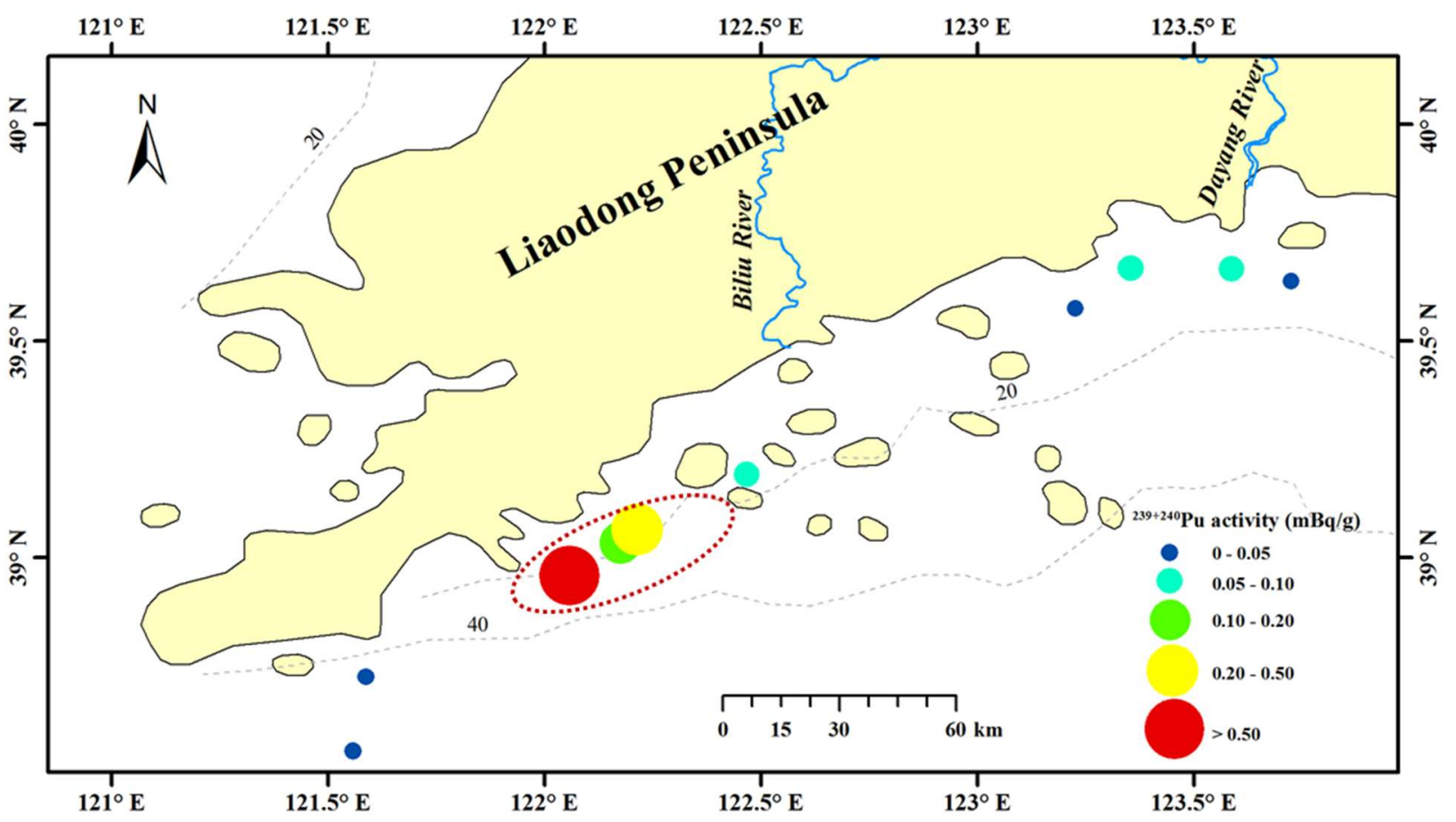

605

606

Figure 4
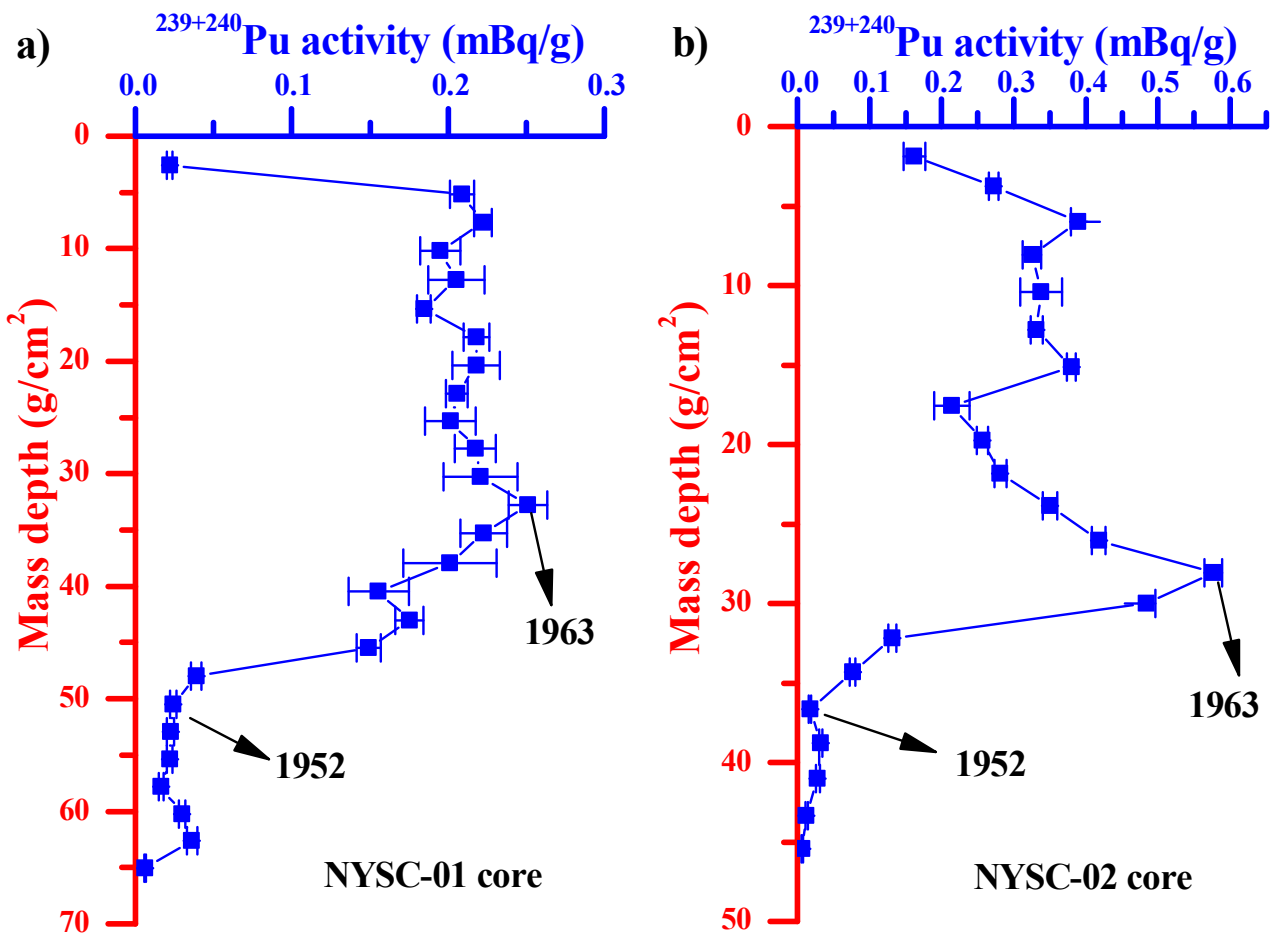

608 Figure 5 


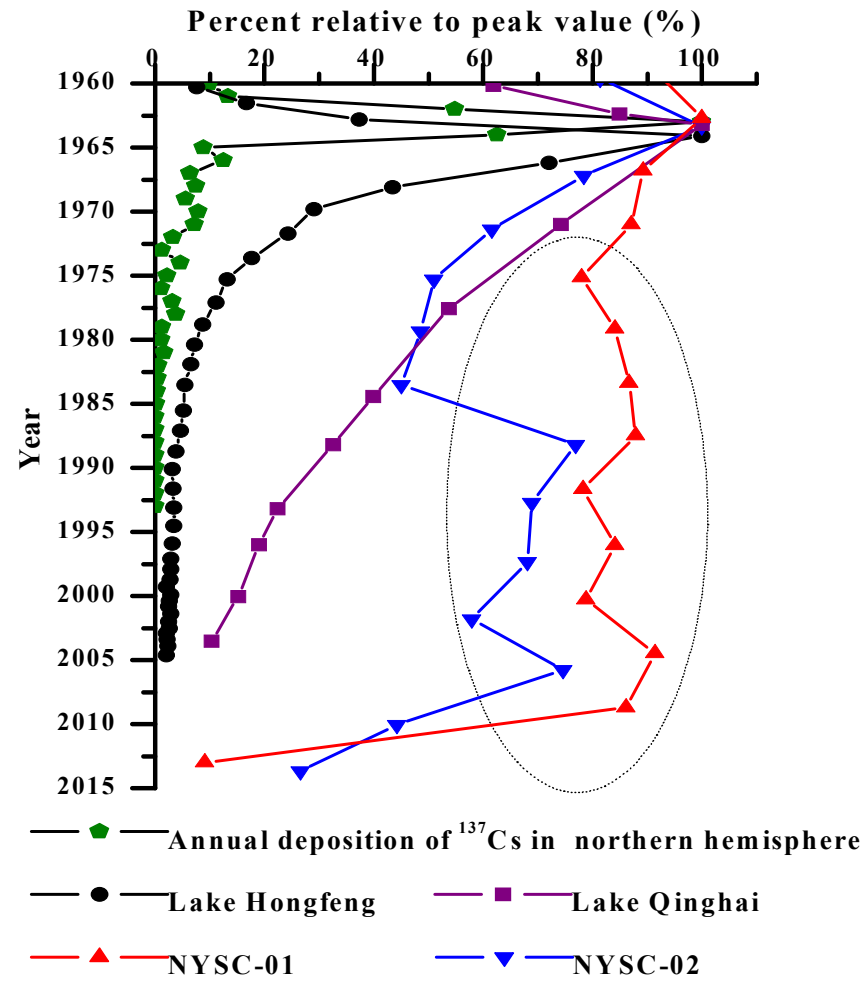

$610 \quad$ Figure 6

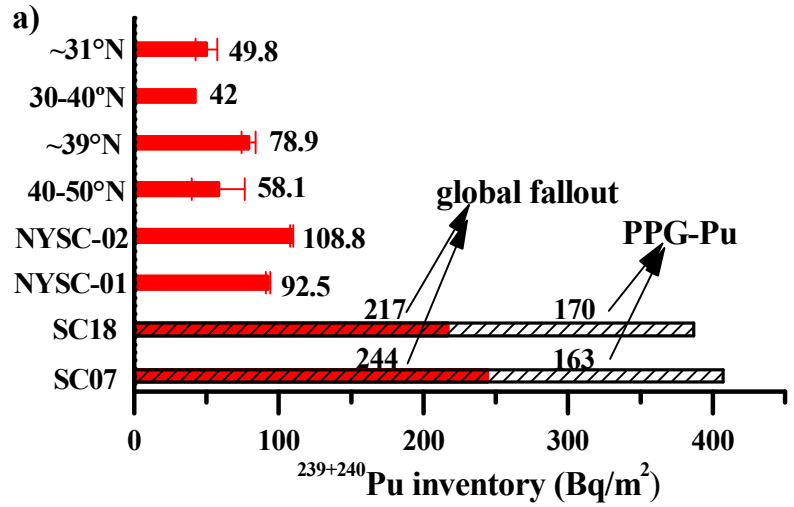

b)

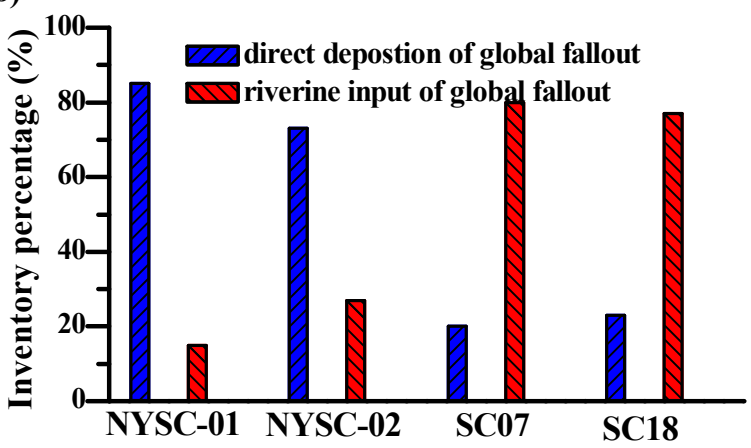



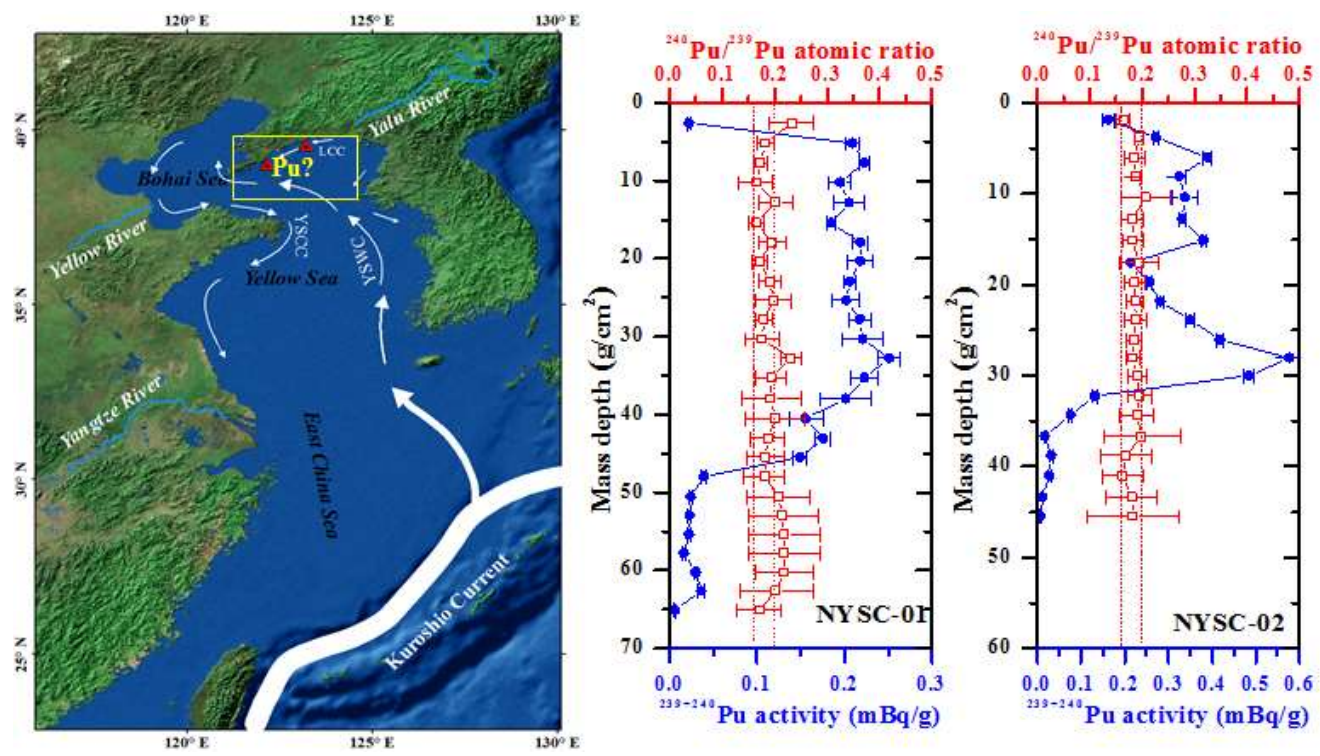